\title{
Usability of CART algorithm for determining egg quality characteristics influencing fertility in the eggs of Japanese quail
}

\author{
Şenol Çelik ${ }^{1}$, Bünyamin Söğüt ${ }^{1}$, Turgay Şengül ${ }^{1}$, Ecevit Eyduran² ${ }^{2}$, Ahmet Yusuf Şengül
}

\author{
${ }^{1}$ Bingol University, Agricultural Faculty, Department of Animal Science, Bingol, Turkey. \\ 2 Iğdir University, Agricultural Faculty, Department of Animal Science, Iğdir, Turkey.
}

\begin{abstract}
The objective of this study was to determine the effects of egg quality characteristics (egg weight, egg width, egg height, and shape index) on fertility of eggs of Japanese quail with different colored feathers (yellow, white, grizzled, and normal), which are of economic importance for poultry production. For this purpose, 383 eggs of Japanese quail with various feather colors were used. In the study, usability of classification and regression tree (CART) data-mining algorithm as a classification tree method is necessary for poultry breeders to define proper cut-off values of egg quality characteristics that ensure Japanese quail eggs at good quality in fertility. Fertility as the dependent variable in the study was examined as a binary trait (fertile and infertile) and all the egg quality traits accepted as explanatory variables were continuous variables. Feather color was also included as a nominal categorical explanatory variable. The classification tree results showed that the highest fertility ratio of $90.9 \%$ was obtained from the eggs of Japanese quail of white, grizzled, and normal feather colors with $10.425 \mathrm{~g} \geq \mathrm{egg}$ weight, $24.565 \mathrm{~mm} \geq$ egg width, or the fertility ratio of $88.2 \%$ of the eggs was observed with $10.425 \mathrm{~g} \leq$ egg weight and 25.605 $\mathrm{mm} \geq$ egg width. Consequently, usability of the tree-based CART algorithm is important in practice for properly establishing fertilized eggs, depending on feather color types of Japanese quail.
\end{abstract}

Key Words: data mining algorithm, quail egg, hatchability

\section{Introduction}

Japanese quail (Coturnix coturnix japonica) is one of the most appropriate animal materials for poultry breeding studies (Alkan et al., 2008). Altan et al. (1998) evaluated the effects of selection in Japanese quail. Turkmut et al. (1999) reported that egg weight, albumen index, and yolk index positively changed during selection of Japanese quail. In quail production, hatchability and fertility are momentous parameters affected by sex ratio, genetic factors, egg characteristics, and parental live body weight and age (Ayasan, 2013). The most determining factors affecting the fertility are season, stock density, and selection taking place in the scope of quail breeding (Kucukonder et al., 2014). Sari et al. (2010) investigated the influence of egg weight, shape index, and parental age on hatchability traits and survival rate for Japanese quail. Storage time and temperature of eggs in managerial condition were reported to be environmental factors affecting fertility trait with low heritability in poultry science (Ozdemir and Inci,

Received March 11, 2016 and accepted July 29, 2016.

Corresponding author: senolcelik@bingol.edu.tr

http://dx.doi.org/10.1590/S1806-92902016001100001

Copyright (C) 2016 Sociedade Brasileira de Zootecnia. This is an Open Access article distributed under the terms of the Creative Commons Attribution License (http://creativecommons.org/licenses/by/4.0/), which permits unrestricted use, distribution, and reproduction in any medium, provided the original work is properly cited.
2012; Celik et al., 2014; Kucukonder et al., 2014). In the determination of optimal conditions for quail production, powerful statistical approaches help breeders to perfectly establish some decisive factors and egg traits on fertility and hatchability. Herewith, as of lately, few studies on data mining algorithms have been conducted for deciding factors and egg characteristics affecting hatchability and fertility in poultry production (Karabag et al., 2010; Kucukonder et al., 2014; Uckardes et al., 2014).

Classification and regression tree (CART) practiced for nominal, ordinal, and continuous variables is the data-mining algorithm used for constructing the decision tree as a good alternative to discriminant analysis and particularly logistic regression analysis (Camdeviren et al., 2007). The tree-based CART algorithm without finding any assumption necessary for explanatory variables is structured by a categorical dependent variable and both categorical and continuous explanatory variables for large data sets (Karabag et al., 2010). The algorithm produces binary nodes by dividing each node into two child nodes, recursively until homogeneous subgroups are obtained in the tree diagram. With the development of computer technology at the present time, statistical analysis of the algorithm is feasible in SAS (Statistical Analysis System), SPSS (Statistical Package for Social Sciences) (Ali et al., 2015), and STATISTICA (Camdeviren et al., 2007; Nisbet et al., 2009; Zaborski et al., 2014) softwares. 
In the classification problems, usage of various datamining algorithms for animal science has recently been recorded for beef cattle (Grzesiak et al., 2014; Kucukonder et al., 2015), dairy cattle (Grzesiak et al., 2010; Grzesiak et al., 2011; Zaborski et al., 2014; Bayram et al., 2015), and fisheries science (Topal et al., 2010). Yet, application of data-mining algorithms for poultry science has been scarce for Japanese quail (Kucukonder et al., 2014; Uckardes et al., 2014) and Chukar partridge (Alectoris chukar) (Karabag et al., 2010). Among the researchers, Uckardes et al. (2014) preferred CHAID (chi-square automatic interaction detector) data-mining algorithm to identify the effects of genotype, season, and cage stocking on fertility for Japanese quail, while Kucukonder et al. (2014) described the influence of season, selection, and cage stocking on fertility of Japanese quail with several classification algorithms. However, we have not yet found the published article on establishing the effect of some egg quality characteristics on fertility for Japanese quail eggs having economic importance for poultry production. The goal of the study was to establish egg quality traits (egg weight, egg width, egg height, and shape index) effecting fertility with the aid of CART data-mining algorithm. It is necessary for quail breeders to recognize proper cut-off values of egg quality characteristics that guarantee fertilized Japanese quail eggs at good quality.

\section{Material and Methods}

The animal material of the current study was composed of 450 quail eggs laid by Japanese quail breeders with four different feather colors (yellow, white, grizzled, and normal) reared in Bingol Province, Turkey. They were housed on six floors, with 40 quail/floor for a time period of seven weeks. All the groups were fed the ration of $23 \%$ crude protein $(\mathrm{CP})$ and $3100 \mathrm{kcal} / \mathrm{kg}$ metabolizable energy during the first week. At subsequent weeks, they were fed the ration of $20 \% \mathrm{CP}$ and $3250 \mathrm{kcal} / \mathrm{kg}$ metabolizable energy. Quail eggs collected from all the color groups were measured as for weight, width, height, and shape index (egg width $\times 100$ /egg height) and then placed in egg incubator. At the end of incubation time of 17 days, hatchability and early embryonic mortality were determined for 383 fertilized eggs, which were obtained from all hatching eggs.

We considered fertility as a binary dependent variable (coded as fertile and infertile). Independent continuous variables assessed in the study were egg quality characteristics, namely, egg weight, egg width, egg height, and shape index. In addition, feather color (yellow, white, grizzled, and normal) was used as a nominal independent variable.
The classification tree of the CART algorithm is recursively constructed by splitting a node (subset) into two child nodes (subsets) until homogenous subsets were produced. As a perfect alternative to logistic regression analysis, the tree-based CART algorithm detects significant explanatory variables affecting a dependent variable (Camdeviren et al., 2007).

We activated pruning option to remove redundant branches in the classification tree structure and regulated minimum numbers of quail in parent and child nodes as $10: 5$ to achieve classification performance at the highest level. V-fold cross validation is accepted as 10 in the CART algorithm. Accuracy of classification rate, sensitivity, and specificity were calculated as defined by Camdeviren et al. (2007).

In the study, CART analysis was conducted using the IBM SPSS 23 program.

\section{Results}

Descriptive statistics of egg characteristics are given in Table 1. Independent variables affecting fertility in Japanese quails were determined by CART algorithm. The tree structure gives some cut off-values, which can contribute to quail breeders in practice (Figure 1). An example of the cut-off values in the tree construction for egg weight was $10.425 \mathrm{~g}$. Nodes coded as $3,7,8,10,11$, and 12 were terminal nodes, since they proved satisfactory homogeneity. Accuracy classification, sensitivity, and specificity ratios were found as $74 \%, 95.2 \%$, and $21 \%$, respectively. Classification and regression tree algorithm predicted the fertilized eggs at the very high ratio of $95.2 \%$, which may be important in practice for Japanese quail breeders. In further investigations, different variables can also be examined. In the normalized importance, the feather color, as an explanatory variable, contributed to the classification tree at the highest ratio $(100 \%)$. It was followed by egg width $(72.7 \%)$, egg height $(46.7 \%)$, and egg weight (39.1\%) (data not shown).

Node 0 had the fertility ratio of $71.3 \%$ in the tree diagram structure and was split by a discriminator, such as egg weight, into two child nodes coded as Node 1

Table 1 - Descriptive statistics for egg characteristics

\begin{tabular}{lccccc}
\hline Variable & $\mathrm{N}$ & Minimum & Maximum & Mean & $\begin{array}{c}\text { Standard } \\
\text { deviation }\end{array}$ \\
\hline Egg weight $(\mathrm{g})$ & 383 & 8.59 & 16.97 & 11.69 & 1.14 \\
Egg width $(\mathrm{mm})$ & 383 & 16.89 & 29.94 & 25.71 & 1.03 \\
Egg height $(\mathrm{mm})$ & 383 & 25.82 & 40.51 & 33.33 & 1.64 \\
Shape index & 383 & 45.78 & 96.58 & 77.27 & 3.96 \\
\hline
\end{tabular}


and Node 2, respectively. Node 1 is the group of eggs weighing $10.425 \mathrm{~g}$ or lighter and presented a fertility ratio of $54.5 \%$ from 44 eggs. When the classification tree was observed with the fertility ratio of $73.5 \%$, Node 2 was the group of eggs whose weight was heavier than $10.425 \mathrm{~g}$. In addition, it was remarked that $88.5 \%$ of all the eggs $(\mathrm{n}=383)$ examined in the quail study were assigned to Node 2 ( $\mathrm{n}=339$ eggs $)$.
The first discriminator for Node 1, split into Node 3 (17 out of 383 eggs) and Node 4 (27 out of 383 eggs), respectively, was feather color as an explanatory variable. Node 3, with the fertility ratio of $29.4 \%$, was the group of eggs whose weight was $10.425 \mathrm{~g}$ or lighter $\mathrm{g}$ in only yellow Japanese quails. Node 4 was the group of eggs whose weight was $10.425 \mathrm{~g}$ or lighter in Japanese quails with white, grizzled, and normal-colored feathers. Node 4, with

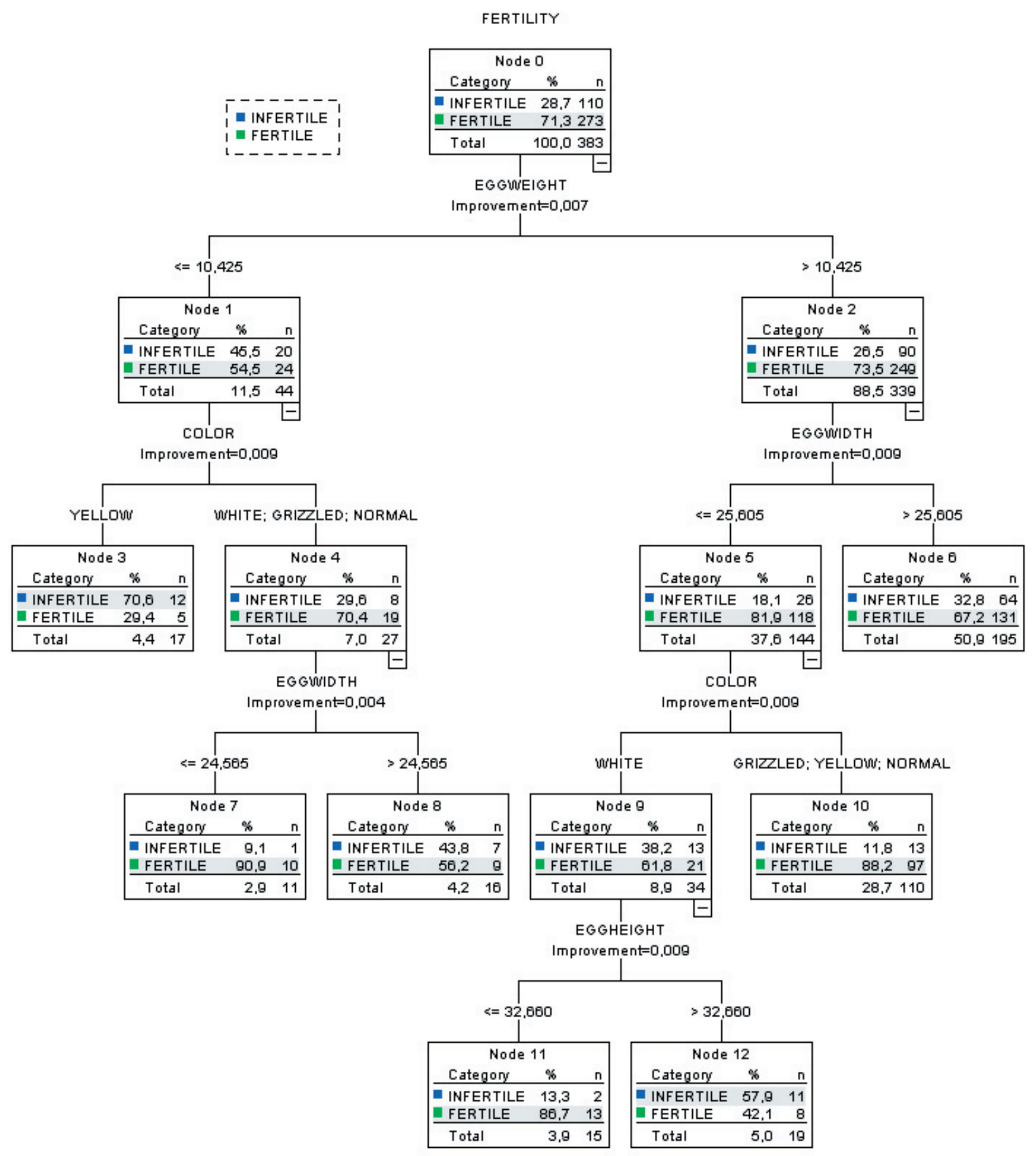

Figure 1 - The classification tree constructed by CART algorithm for fertility ratio. 
the fertility ratio of $70.4 \%$, was characterized by fertilized eggs, but Node 3 was characterized by unfertilized eggs. Nodes 7 and 8 were obtained from Node 4 . Node 7 is the group of eggs whose weight was $10.425 \mathrm{~g}$ or lighter and whose width was $24.565 \mathrm{~mm}$ or narrower for Japanese quail with white, grizzled, and normal-colored feathers. The highest fertility ratio of $90.9 \%$ was obtained from the eggs in Node 7, which was obtained from Node 4 to characterize fertilized eggs very well. Node 8 was the group of eggs whose weight was $10.425 \mathrm{~g}$ or lighter and whose width was wider than $24.565 \mathrm{~mm}$ for white, grizzled, and normal-colored feathers. Node 2 was partitioned by egg width into two child nodes, Node 5 and Node 6 , with the fertility ratios of $81.9 \%$ and $67.2 \%$, respectively. The group named as Node 5 was of eggs whose weight was heavier than $10.425 \mathrm{~g}$ and whose width was $25.605 \mathrm{~mm}$ or narrower. As a terminal node, Node 6 was the group of eggs whose weight was heavier than $10.425 \mathrm{~g}$ and whose width was wider than $25.605 \mathrm{~mm}$. Node 5 was divided into Node 9 and Node 10 according to color variable. Node 9 , split by egg height into Node 11 and Node 12, was the group of eggs whose weight was heavier than $10.425 \mathrm{~g}$ and whose width was $25.605 \mathrm{~mm}$ or narrower in only white Japanese quails. It also provided the fertility ratio of $61.8 \%$. Node 10 , with the fertility ratio of $88.2 \%$, was the group of eggs whose weight was heavier than $10.425 \mathrm{~g}$ and whose width was $25.605 \mathrm{~mm}$ or narrower for Japanese quails with grizzled, yellow, and normal feather colors. With the fertility ratio of $86.7 \%$, Node 11 was the group of the white Japanese quail eggs whose egg weight was heavier than $10.425 \mathrm{~g}$, whose egg width was $25.605 \mathrm{~mm}$ or narrower, and whose height was $32.660 \mathrm{~mm}$ or shorter. Node 12 was the group of the white Japanese quail eggs whose egg weight was heavier than $10.425 \mathrm{~g}$, whose egg width was $25.605 \mathrm{~mm}$ or narrower, and whose height was taller than $32.660 \mathrm{~mm}$.

\section{Discussion}

Dudusola (2013) reported better outcomes in hatchability (96.05\% and $95.74 \%)$ and fertility (95\% and $94 \%$ ) at 22 weeks of age in comparison with 36 weeks of age for light and heavy egg weight groups of Japanese quail. Studying the influence of cage type and mating ratio on fertility of the eggs of Japanese quail, Narinc et al. (2013) noticed that the higher fertility ratios of 87.43 and $84.26 \%$ were estimated for the quails housed in individual cages and colony cages, respectively, compared with the overall fertility ratio in the study. The current general fertility ratio was lower than the ratio (82\%) given as a result of selection studies in Uckardes et al. (2014). However, the authors found the highest fertility ratios for control line (96.4\%) and selection line (90.6\%) at a stocking density of 240 $\mathrm{cm}^{2} /$ quail in autumn in the CHAID analysis. The highest fertility ratio $(90.9 \%)$ was recorded for the eggs whose weight and width were $10.425 \mathrm{~g}$ or lighter and $24.565 \mathrm{~mm}$ or narrower in other colored quail except for yellow quails in the current data. However, the present highest ratio was slightly lower in comparison with the corresponding ratios informed by Uckardes et al. (2014). The main difference for fertility in literature may be attributed to usage of different factors (cage type, stocking density, mating ratio, and rearing system etc.), sample size, data-mining algorithms, and especially selection. The current visual data proved that the fertility ratio could vary based on feather color groups of Japanese quails when some nodes (Node 3 vs. Node 4 and Node 9 vs. Node 10) were examined. The color factor had much more contribution $(100 \%$ normalized importance) in the construction of the classification tree diagram compared with other egg quality characteristics in the study. As in fattening performance, carcass, and egg quality characteristics (Inci et al., 2015), the fertility of the quail eggs should be considered in respect to different feather colors. The knowledge may be profitable for further relevant studies due to economic factors.

It was observed that $88.5 \%$ of the eggs obtained in the study were found heavier than $10.425 \mathrm{~g}$ (Node 2). Turkmut et al. (1999) reported that egg weight could be improved through selection program. Kucukonder et al. (2014) mentioned the importance of selection studies in fertility with major factors such as season and stock density. The present results are important for improving fertility and hatchability of Japanese quail.

Accuracy classification ratio (74\%) for the classification tree constructed by the CART algorithm was lower compared with Kucukonder et al. (2014), with accuracy classification ratios of $85.71,91.58,98.59,91.06$, and 99.73\% for Naïve Bayes, KSTAR, ANN, RBF Network, and Ridor data-mining algorithms, respectively. The difference may be occurring as a result of differentness in handled factors, data mining algorithms, other management conditions, and genetic level. However, CART algorithm produces a decision tree diagram and the visual results are easier to interpret compared with the algorithms specified by Kucukonder et al. (2014).

It could be stated that the current classification tree data revealed more different information about fertility compared with similar studies. Nodes numbered 7, 10, and 11 produced the highest fertility ratios, which may be baseline information for further selection studies. Additionally, the classification tree result revealed that 
Nodes numbered $0,1,2,4,5,6,7,8,9,10$, and 11 were characterized with fertilized eggs (fertile), but only two nodes numbered 3 and 12 were characterized with unfertilized eggs (infertile).

Since fertilized eggs positively affected hatching success, nodes producing high-fertilized ratio might be useful for quail producers in the practice.

\section{Conclusions}

The feather color factor should be taken into account for fertility ratio of Japanese quail in further (selection) studies together with characteristics such as weight, width, and height of the eggs, and the implementation of CART algorithm in next studies will produce beneficial reference in practice for detecting other characteristics affecting fertility in order to develop egg quality standards in it for the studied quail.

\section{References}

Ali, M.; Eyduran, E.; Tariq, M. M.; Tirink, C.; Abbas, F.; Bajwa, M. A.; Baloch, M. H.; Nizamani, A. H.; Waheed, A.; Awan, M. A.; Shah, S. H.; Ahmad, Z. and Jan S. 2015. Comparison of artificial neural network and decision tree algorithms used for predicting live weight at post weaning period from some biometrical characteristics in Harnai sheep. Pakistan Journal of Zoology 47:1579-1585.

Alkan, S.; Galiç, A.; Karabağ, K. and Balcioglu, M. S. 2008. Effects of selection for live weight and egg weight on hatching and 6 week body weights in Japanese quails (Coturnix coturnix japonica). Hayvansal Üretim 49:16-19.

Altan, O.; Oguz, I. and Akbas, Y. 1998. Effects of selection for high body weight and age of hen on egg characteristics in Japanese quail (Coturnix coturnix japonica). Turkish Journal of Veterinary and Animal Sciences 22:467-473.

Ayasan, T. 2013. Effects of dietary inclusion of protexin (probiotic) on hatchability of Japanese quails. Indian Journal of Animal Sciences $83: 78-81$

Ayasan, T. 2013. Effects of dietary Yucca schidigera on hatchability of Japanese quails. Indian Journal of Animal Sciences 83:641-644.

Bayram, B.; Topal, M.; Aksakal, V. and Onk, K. 2015. Investigate the effects of non-genetic factors on calving difficulty and stillbirth rate in Holstein Friesian cattle using the CHAID analysis. Kafkas Universitesi Veteriner Fakultesi Dergisi 21:645-652.

Camdeviren, H. A.; Yazici, A. C.; Akkus, Z.; Bugdayci, R. and Sungur, M. A. 2007. Comparison of logistic regression model and classification tree: An application to postpartum depression data. Expert Systems with Applications 32:987-994.

Celik, S.; Inci, H.; Sengul, T.; Sogut, B. and Kayaokay, A. 2014. Japon Bıldırcınlarda Yumurta Kalite Özellikleri Üzerine Farklı Tüy Renginin Etkileri. Yüzüncü Yıl Üniversitesi Tarım Bilimleri Dergisi 24:248-256.

Dudusola, I. O. 2013. The effect of parental age and egg weight on fertility, hatchability and day-old chick weight of Japanese quail
(Cortunix cortunix japonica). Standard Research Journal of Agricultural Sciences 1:13-16.

Grzesiak, W.; Zaborski, D.; Sablik, P.; Żukiewicz, A.; Dybus, A. and Szatkowska, I. 2010. Detection of cows with insemination problems using selected classification models. Computers and Electronic in Agriculture 74:265-273.

Grzesiak, W.; Zaborski, D.; Sablik, P. and Pilarczyk, R. 2011. Detection of difficult conceptions in dairy cows using selected data mining methods. Animal Science Papers and Reports 29:293-302.

Grzesiak, W.; Rzewucka-Wójcik E.; Zaborski D.; Szatkowska I.; Kotarska K. and Dybus A. 2014. Classification of daily body weight gains in beef cattle via neural Networks and decision trees. American Society of Agricultural and Biological Engineers 30:307-313. doi: 10.13031/aea.30.10135.

Inci, H.; Sogut, B.; Sengul, T.; Sengul, A. Y. and Taysi, M. R. 2015. Comparison of fattening performance, carcass characteristics, and egg quality characteristics of Japanese quails with different feather colors. Revista Brasileira de Zootecnia 44:390-396.

Karabag, K.; Alkan, S. and Mendes, M. 2010. Classification tree method for determining factors that affecting hatchability in Chukar partridge (Alectoris chukar) eggs. Kafkas Universitesi Veteriner Fakultesi Dergisi 16:723-727.

Kucukonder, H.; Uckardes, F. and Narinc, D. 2014. A data mining application in animal breeding: Determination of some factors in Japanese quail eggs affecting fertility Kafkas Universitesi Veteriner Fakultesi Dergisi 20:903-908.

Kucukonder, H.; Uckardes, F.; Ceyhan, A. and Cinar, M. 2015. Determination of the effect of somatic cell count on udder measurements and subclinical mastitis with data mining method. Pakistan Veterinary Journal 35:441-445.

Narinc, D.; Aygun A. and Sari T. 2013. Effects of cage type and mating ratio on fertility in Japanese quails (Coturnix Coturnix Japonica) eggs. Agriculture Science Developments 2:4-7.

Nisbet E. K. L.; Zelenski J. M. and Murphy S. A. 2009. The nature relatedness scale: linking individuals' connection with nature to environmental concern and behavior. Environment and Behavior 41:715-740. doi: 10.1177/0013916508318748.

Ozdemir, G. and Inci, H. 2012. The effect of live weight of Japan quail on the characteristics of interior and exterior quality of eggs. Journal of Animal and Veterinary Advances 11:1666-1668.

Sari, M.; Tilki, M.; Saatci, M.; Isik, S. and Onk, K. 2010. Effect of parental age, egg weight and shape index on hatchability traits and live ability in Japanese quail (Coturnix coturnix japonica). Firat Universitesi Sağlık Bilimleri ve Veteriner Dergisi 24:93-97.

Topal, M.; Yaganoglu, A. M.; Sonmez, A. Y.; Arslan, G. and Hisar O. 2010. Using discriminant and CHAID analysis methods to identify sex in brown trout (Salmo trutta fario) by morphometric features. The Israeli Journal of Aquaculture-Bamidgeh 62:251-259.

Turkmut, L.; Altan, Z.; Oguz, J. and Yalcin, S. 1999. Effect of selection for four week body weight on slaughter, carcass, and abdominal fat and some organ weights and blood serum parameters in Japonica quail. Turkish Journal Veterinary and Animal Science 23:63-68.

Uckardes, F.; Narinc, D. and Kucukonder, H. 2014. Application of classification tree method to determine factors affecting fertility in Japanese quail eggs. Journal of Animal Science Advances 4:1017-1023.

Zaborski, D.; Grzesiak, W.; Kotarska, K.; Szatkowska, I. and Jedrzejczak, M. 2014. Detection of difficult calvings in dairy cows using boosted classification trees. Indian Journal of Animal Research 48:452-458. doi: 10.5958/0976-0555.2014.00010.7 